\title{
Measuring Congruence of Ranking Results Applying Particular MCDM Methods
}

\author{
Jurgita ANTUCHEVICIENE, Algimantas ZAKAREVICIUS, \\ Edmundas Kazimieras ZAVADSKAS \\ Vilnius Gediminas Technical University \\ Saulètekio al. 11, LT-10223, Vilnius, Lithuania \\ e-mail: jurgita.antucheviciene@vgtu.lt,algimantas.zakarevicius@vgtu.lt, \\ edmundas.zavadskas@vgtu.lt
}

Received: August 2011; accepted: September 2011

\begin{abstract}
The aim of the current research is to measure objective congruence (incongruence) of the results obtained in a process of multiple criteria analysis when applying different MCDM methods. The methodology for evaluation of ranking results is developed on the ground of a case study of the redevelopment of derelict buildings as well as on composed experimental tasks. Fuzzified COPRAS, TOPSIS and VIKOR methods are applied for ranking the alternatives. Calculation results are evaluated by applying mathematical statistics methods. A methodology for measuring the congruence (incongruence) of the relative significances of alternatives is proposed.
\end{abstract}

Keywords: MCDM, COPRAS, TOPSIS, VIKOR, congruence of ranking results.

\section{Introduction}

Multiple criteria decision making (MCDM) can be applied for complex decisions when a lot of criteria are involved. There is a variety of MCDM methods developed as well as case studies of their application presented. However, it was observed that different MCDM methods can produce diverse, not always coinciding ranking results. Therefore, in the current paper the authors suggest applying COPRAS (a method of multiple criteria COmplex PRoportional ASsessment of projects), TOPSIS (the Technique for Order Preference by Similarity to Ideal Solution) based on vector as well as linear normalization of initial criteria values and VIKOR (VlseKriterijumska Optimizacija I Kompromisno Resenje; in Serbian) methods for ranking of alternatives as well as compare and analyze calculation results.

Zavadskas and Kaklauskas (1996) developed a method of multiple criteria complex proportional assessment of projects for determining the priority and the utility degree of alternatives. Lithuanian as well as foreign scientists have been applying the original or expanded method for solving different engineering and management multi-attribute problems in the period of 1996-2011 (Zavadskas et al., 2009a; Mazumdar et al., 2010; Podvezko et al., 2010; Chatterjee et al., 2011). Some other authors have been applying modified COPRAS method. Zavadskas and Antucheviciene (2007) applied fuzzified COPRAS 
method and performed a multiple criteria analysis of regeneration alternatives of derelict buildings in Lithuanian rural areas. Zavadskas et al. (2009b) considered the application of grey relations methodology for defining the utility of alternatives (COPRAS-G). The compromise ranking method with grey numbers was also used by Madhuri et al. (2010), Madhuri and Chandulal (2010).

Usual crisp TOPSIS as developed by Hwang and Yoon (1981) or fuzzy TOPSIS has been widely applied in construction management for ranking of constructiontechnological alternatives, selecting of resource-saving decisions, accepting other technological or facility management decisions (Zavadskas and Antucheviciene, 2006; Liu, 2009; Liaudanskiene et al., 2009; Kucas, 2010; Kalibatas et al., 2011). The above method was successfully applied for selecting of various projects (Amiri, 2010), suppliers (Boran et al., 2009), partners or contractors (Marzouk, 2008; Ye, 2010), consultants (Saremi et al., 2009), evaluating road design and transport systems (Jakimavicius and Burinskiene, 2009). In some papers the application of extended TOPSIS has been analyzed. In Zavadskas et al. (2006) the methodology for measuring the accuracy of determining the relative significance of alternatives as a function of the criteria values was developed. A new fuzzy multicriteria decision making approach for evaluating decision alternatives involving subjective judgments made by a group of decision makers was presented in Yeh and Chang (2009) paper. Attempts using extended TOPSIS method with different distance approaches were published (Antucheviciene et al., 2010; Chang et al., 2010).

Compromise ranking method (VIKOR) was developed and presented by Opricovic (1998) as well as VIKOR and TOPSIS methods were compared by Opricovic and Tzeng (2004). According to Opricovic and Tzeng, the values normalized by vector normalization and applied in TOPSIS may depend on the evaluation unit. Moreover, these two methods introduce different aggregating functions for ranking. Therefore, the authors of the current paper also applied the VIKOR method for ranking redevelopment alternatives of derelict buildings (Antucheviciene and Zavadskas, 2008). The VIKOR-F method has been developed to solve fuzzy multicriteria problem with conflicting and noncommensurable criteria (Opricovic, 2007).

However, combination of VIKOR with some other MCDM methods has been more often applied and handling of a proper MCDM technique has been discussed. Selection of proper methods considering their advantages and disadvantages in qualitative manner was analysed in Ginevicius and Zubrecovas (2009), Ginevicius and Podvezko (2009). TOPSIS and VIKOR were applied for evaluating of environment of enterprises (Ginevicius et al., 2010). The Comparative Analysis of SAW and COPRAS was carried out by Podvezko (2011). Ic and Yurdakul (2010) compared results of decision support system based on fuzzy TOPSIS with experts' opinion. Spearman's correlation was used for that purpose. Hajkowicz and Higgins (2008) applied some other multiple criteria assessment methods to water management decision problems and showed that different methods were in strong agreement with high correlations amongst rankings.

The aim of the current research is to measure objective congruence (incongruence) of the results obtained in a process of multiple criteria analysis when applying different MCDM methods. The methodology for evaluating of ranking results is developed on the 
ground of a case study of redevelopment of derelict buildings as well as on composed experimental tasks. Calculation results are evaluated by applying mathematical statistics methods. The methodology for measuring the congruence (incongruence) of the relative significances of building redevelopment alternatives is proposed. The above methodology is applicable for analyzing the results of different multi-attribute tasks.

\section{MCDM Methods Applied for Ranking of Building Redevelopment Alternatives}

The methods evaluate the decision matrix $F$, which refers to $n$ alternatives that are evaluated in terms of $m$ criteria. The system of criteria and alternatives as well as the initial values and weights of criteria are determined.

Suppose, there is the initial decision-making matrix:

$$
F=\left(\begin{array}{cccc}
f_{11} & f_{12} & \ldots & f_{1 n} \\
f_{21} & f_{22} & \ldots & f_{2 n} \\
\vdots & \vdots & \vdots & \vdots \\
f_{m 1} & f_{m 2} & \cdots & f_{m n}
\end{array}\right)
$$

where $m$ is a number of criteria and $n$ is a number of alternatives. The member $f_{i j}$ denotes the performance measure of the $j$ th alternative in terms of the $i$ th criterion, $i=1, \ldots, m$; $j=1, \ldots, n$.

Then the weighted normalized decision-making matrix is formed and the relative significances as well as a priority order of alternatives is established applying a particular MCDM method as described in the following subsections.

\subsection{COPRAS}

According to the method of multiple criteria COmplex PRoportional ASsessment of projects, a generalized criterion determining the complex efficiency of the project is directly proportional to the relative effect of values and weights of the criteria considered in a project.

To eliminate the units of the criterion functions and to receive the weighted values, the method under discussion uses the following formula (Zavadskas and Kaklauskas, 1996):

$$
w_{i j}=q_{i} \frac{f_{i j}}{\sum_{j=1}^{n} f_{i j}}
$$

where $q_{i}$ is the weight of $i$ th criterion, $w_{i j}$ is the normalized weighted value of each criterion, $i=1, \ldots, m ; j=1, \ldots, n$.

Then the sums of weighed normalized values of criteria describing the $j$ th alternative are calculated. Following the (2), $w_{i j}, i=1, \ldots, m, j=1, \ldots, n$ is the normalized weighted value of each $i$ th criterion, that belongs to benefit criteria or 
cost/loss criteria. Accordingly, the $j$ th alternative is then described by maximizing indices $w_{i j}^{*}, i=1, \ldots, m$, and $i$ is associated with benefit criteria, and minimizing indices $w_{i j}^{-}, i=1, \ldots, m$, and $i$ is associated with cost/loss criteria.

Maximizing indices $w_{i j}^{*}$ and minimizing indices $w_{i j}^{-}$are summed up separately for every $j$ th alternative. The sums of weighted normalized maximizing and minimizing indices $S_{j}^{*}$ and $S_{j}^{-}$, respectively, characterizing the $j$ th alternative, are calculated as follows (Zavadskas and Kaklauskas, 1996):

$$
\begin{aligned}
& S_{j}^{*}=\sum_{i=1}^{m} w_{i j}^{*}, \\
& S_{j}^{-}=\sum_{i=1}^{m} w_{i j}^{-},
\end{aligned}
$$

The relative significance $Q_{j}$ of each alternative is determined according to positive $S_{j}^{*}$ and negative $S_{j}^{-}$and is calculated by the formula (Zavadskas and Kaklauskas, 1996):

$$
Q_{j}=S_{j}^{*}+\frac{S_{\min } \cdot \sum_{j=1}^{n} S_{j}^{-}}{S_{j}^{-} \cdot \sum_{j=1}^{n} \frac{S_{\min }}{S_{j}^{-}}},
$$

where $S_{\min }=\min _{j} S_{j}^{-}, j=1, \ldots, n$.

Then the priorities of alternatives can be determined. Relative significance $Q_{j}$ of the $j$ th alternative indicates the satisfaction degree of demands and goals pursued by the interested parties. The greater the value of the generalizing criterion $Q_{j}$, the more effective is the alternative. In the case of $Q_{\max }=\max _{j} Q_{j}, j=1, \ldots, n$, the satisfaction degree as well as the priority (rank) of the alternative is the highest. The rank of the remaining variants is lower compared with the most rational alternative.

\subsection{TOPSIS Based on Two Criteria Values' Normalization Methods}

Considering the opinion, that there are normalization procedures with effects on the final MCDM result, two normalization methods were used in the TOPSIS technique. The classical TOPSIS uses vector normalization (Hwang and Yoon, 1981; Triantaphyllou, 2000):

$$
r_{i j}=\frac{f_{i j}}{\sqrt{\sum_{j=1}^{n} f_{i j}^{2}}},
$$

where $r_{i j}$ is the normalized value, $i=1, \ldots, m ; j=1, \ldots, n$.

Lai and Hwang (1994) introduced linear normalization into the TOPSIS:

$$
r_{i j}=\frac{f_{i j}}{f_{i}^{*}-f_{i}^{-}},
$$

where $f_{i}^{*}=\max _{j} f_{i j}, f_{i}^{-}=\min _{j} f_{i j}, i=1, \ldots, m ; j=1, \ldots, n$. 
The weighted normalized value $w_{i j}$ is calculated as

$$
w_{i j}=q_{i} r_{i j}
$$

where $q_{i}$ is the weight of $i$ th criterion, $i=1, \ldots, m ; j=1, \ldots, n$.

The ideal and the negative-ideal solutions denoted respectively as $A^{*}$ and $A^{-}$are defined as follows (Hwang and Yoon, 1981; Triantaphyllou, 2000):

$$
\begin{aligned}
& A^{*}=\left\{w_{1}^{*}, w_{2}^{*}, \ldots, w_{m}^{*}\right\} \\
& A^{-}=\left\{w_{1}^{-}, w_{2}^{-}, \ldots, w_{m}^{-}\right\}
\end{aligned}
$$

where $w_{i}^{*}=\max _{j} w_{i j}, w_{i}^{-}=\min _{j} w_{i j}, i=1, \ldots, m ; j=1, \ldots, n$, if the $i$ th criterion represents a benefit; $w_{i}^{*}=\min _{j} w_{i j}, w_{i}^{-}=\max _{j} w_{i j}, i=1, \ldots, m ; j=1, \ldots, n$, if the $i$ th criterion represents a cost/loss.

The Euclidean distance method is then applied to measure the distances of each alternative from the ideal solution and negative-ideal solution:

$$
\begin{aligned}
& S_{j}^{*}=\sqrt{\sum_{i=1}^{m}\left(w_{i j}-w_{i}^{*}\right)^{2}}, \\
& S_{j}^{-}=\sqrt{\sum_{i=1}^{m}\left(w_{i j}-w_{i}^{-}\right)^{2}},
\end{aligned}
$$

where $S_{j}^{*}$ is the distance from the ideal solution and $S_{j}^{-}$is the distance from the negativeideal solution, $i=1, \ldots, m ; j=1, \ldots, n$.

The relative closeness of an alternative $A_{j}$ to the ideal solution $A^{*}$, i.e., the relative significance of an alternative $Q_{j}$ is defined as follows:

$$
Q_{j}=\frac{S_{j}^{-}}{S_{j}^{*}+S_{j}^{-}}
$$

where $1 \geqslant Q_{j} \geqslant 0$ and $j=1, \ldots, n$.

The best alternative can be found according to the preference order of $Q_{j}$.

\subsection{VIKOR}

At first applying the compromise ranking algorithm one needs to determine the best $x_{i}^{*}$ and the worst $x_{i}^{-}$values of all criterion functions, $i=1, \ldots, m$ and to calculate the weighted normalized values $w_{i j}$ :

$$
w_{i j}=q_{i} \frac{x_{i}^{*}-x_{i j}}{x_{i}^{*}-x_{i}^{-}}
$$


where $x_{i}^{*}=\max _{j} x_{i j}, x_{i}^{-}=\min _{j} x_{i j}$ if the $i$ th function represents a benefit and $x_{i}^{*}=$ $\min _{j} x_{i j}, x_{i}^{-}=\max _{j} x_{i j}$ if the $i$ th function represents a cost/loss, $q_{i}$ is the weight (or significance) of the $i$ th criterion, $i=1, \ldots, m ; j=1, \ldots, n$ (Opricovic and Tzeng, 2004).

The next step is the computation of the values $S_{j}, R_{j}$, and $Q_{j}$ :

$$
\begin{aligned}
S_{j} & =\sum_{i=1}^{m} w_{i j}, \\
R_{j} & =\max _{i} w_{i j}, \\
Q_{j} & =v\left(S_{j}-S^{-}\right) /\left(S^{*}-S^{-}\right)+(1-v)\left(R_{j}-R^{-}\right) /\left(R^{*}-R^{-}\right),
\end{aligned}
$$

where $S^{*}=\max _{j} S_{j}, S^{-}=\min _{j} S_{j}, R^{*}=\max _{j} R_{j}, R^{-}=\min _{j} R_{j}, i=1, \ldots, m$; $j=1, \ldots, n, \nu$ is introduced as the weight of the strategy of "the maximum group utility". Here, $\nu=0.5$, meaning that a compromise solution is stable within the decisionmaking process by consensus. (When $\nu>0.5$, 'voting by majority rule' is needed; when $\nu<0.5$, the solution is stable within the decision-making process 'with veto'.)

Then, the alternatives should be sorted by values $S, R$ and $Q$ in the increasing order. The best alternative $A^{\prime}$ is the one with the minimum value $Q$, if two complementary conditions are satisfied (Opricovic and Tzeng, 2004):

C1. 'Acceptable advantage': $Q\left(A^{\prime \prime}\right)-Q\left(A^{\prime}\right) \geqslant D Q$, where $A^{\prime \prime}$ is the alternative having the second position in the ranking list by $Q ; D Q=1 /(J-1) ; J$ is the number of the alternatives.

C2. 'Acceptable stability in decision-making': $A^{\prime}$ must also be the best ranked by $S$ or/and $R$.

If one of the conditions is not satisfied, then, a set of compromise solutions with the advantage rate is proposed instead of the only best alternative. This will consist of the alternatives $A^{\prime}$ and $A^{\prime \prime}$, if only condition $\mathrm{C} 2$ is not satisfied, or the alternatives $A^{\prime}, A^{\prime \prime}, \ldots, A^{(N)}$, if condition $\mathrm{C} 1$ is not satisfied, while and $A^{(N)}$ is determined by the relation $Q\left(A^{(N)}\right)-Q\left(A^{\prime}\right)<D Q$ for the maximum $N$ (the positions of these alternatives are 'in closeness').

\subsection{Some Items of Fuzzy Sets Theory, as Applied to MCDM}

Considering the fuzziness of the available data and the decision-making procedures, fuzzy numbers could be used to assess the values of all criteria and provide the relative significances of each alternative with respect to each criterion. Hereby, we can convert the decision making matrix (1) into a fuzzy decision making matrix.

\section{Fuzzy Numbers}

Fuzzy numbers are a fuzzy subset of real numbers, representing the expansion of the idea of a confidence interval. In this paper the triangular fuzzy numbers are used for fuzzy numbers. A triangular fuzzy number $\tilde{f}$ can be defined by a triplet $\left(f_{1}, f_{2}, f_{3}\right)$. 
The membership function $\mu_{\tilde{f}}$ of $\tilde{f}$ is defined as (Hwang and Yoon, 1981; Sanayei et al., 2010):

$$
\mu_{\tilde{f}}(x)= \begin{cases}0, & x<f_{1} \\ \frac{x-f_{1}}{f_{2}-f_{1}} & \left(f_{1} \leqslant x \leqslant f_{2}\right), \\ \frac{x-3_{3}}{f_{2}-f_{3}} & \left(f_{2} \leqslant x \leqslant f_{3}\right) \\ 0, & x>f_{3}\end{cases}
$$

The operations on fuzzy triangular numbers used in this research are defined as follows (Sanayei et al., 2010):

Addition of a triangular fuzzy number

$$
\tilde{f}(+) \tilde{f}^{\prime}=\left(f_{1}, f_{2}, f_{3}\right)(+)\left(f_{1}^{\prime}, f_{2}^{\prime}, f_{3}^{\prime}\right)=\left(f_{1}+f_{1}^{\prime}, f_{2}+f_{2}^{\prime}, f_{3}+f_{3}^{\prime}\right),
$$

Subtraction of a triangular fuzzy number

$$
\tilde{f}(-) \tilde{f}^{\prime}=\left(f_{1}, f_{2}, f_{3}\right)(-)\left(f_{1}^{\prime}, f_{2}^{\prime}, f_{3}^{\prime}\right)=\left(f_{1}-f_{1}^{\prime}, f_{2}-f_{2}^{\prime}, f_{3}-f_{3}^{\prime}\right),
$$

Multiplication of a triangular fuzzy number

$$
\tilde{f}(\times) \tilde{f}^{\prime}=\left(f_{1}, f_{2}, f_{3}\right)(\times)\left(f_{1}^{\prime}, f_{2}^{\prime}, f_{3}^{\prime}\right)=\left(f_{1} \times f_{1}^{\prime}, f_{2} \times f_{2}^{\prime}, f_{3} \times f_{3}^{\prime}\right),
$$

Division of a triangular fuzzy number

$$
\tilde{f}(/) \tilde{f}^{\prime}=\left(f_{1}, f_{2}, f_{3}\right)(/)\left(f_{1}^{\prime}, f_{2}^{\prime}, f_{3}^{\prime}\right)=\left(f_{1} / f_{3}^{\prime}, f_{2} / f_{2}^{\prime}, f_{3} / f_{1}^{\prime}\right),
$$

where $\tilde{f}=\left(f_{1}, f_{2}, f_{3}\right)$ and $\tilde{f}^{\prime}=\left(f_{1}^{\prime}, f_{2}^{\prime}, f_{3}^{\prime}\right)$ represent two fuzzy triangular numbers with lower, modal and upper values, respectively.

\section{A Linguistic Variable}

A linguistic variable is a variable with lingual expression as its values. Fuzzy numbers can also represent these linguistic variables. The corresponding relations between linguistic variables and positive triangular fuzzy numbers are given in Table 1 .

The values of qualitative criteria and the weights, evaluating different redevelopment strategies in particular areas, are considered as linguistic variables in the current research.

\section{Defuzzification}

The results of fuzzy decisions are fuzzy numbers. Consequently, a problem of ranking fuzzy numbers appears in multiple criteria decision making. Concerning the peculiarities of this study where the crisp ranking methods COPRAS, TOPSIS and VIKOR have been applied, a defuzzification was performed. Defuzzification is a technique used to convert the fuzzy number into a crisp real number. The procedure of defuzzification is to locate the Best Non-fuzzy Performance (BNP) value. Various methods of defuzzification 
Table 1

The relationships between linguistic variables and triangular fuzzy numbers

\begin{tabular}{ll}
\hline Linguistic variables & Triangular fuzzy numbers \\
\hline Very poor (very light) & $(0 ; 0.1 ; 0.2)$ \\
Poor (light) & $(0.2 ; 0.3 ; 0.4)$ \\
Fair & $(0.4 ; 0.5 ; 0.6)$ \\
Good (difficult) & $(0.6 ; 0.7 ; 0.8)$ \\
Very good (very difficult) & $(0.8 ; 0.9 ; 1)$ \\
\hline
\end{tabular}

are available, e.g., mean-of-maximum, center-of-area, $\alpha$-cut method (Van Leekwijck and Kerre, 1999). In this research the center-of-area method is used. The defuzzified value of a fuzzy number is obtained by applying the equation:

$$
\mathrm{BNP}=\left[\left(f_{3}-f_{1}\right)+\left(f_{2}-f_{1}\right)\right] / 3+f_{1},
$$

where BNP is the Best Non-fuzzy Performance value, $f_{2}$ is a mode, $f_{1}$ and $f_{3}$ are the lower and the upper limits of fuzzy triangular number $\tilde{f}$, respectively.

\section{Multiple Criteria Analysis of Building Redevelopment Alternatives}

\subsection{Problem Formulation and Initial Data - A Case Study of Lithuania}

The case study of multiple criteria evaluation of possible building redevelopment decisions is presented and revitalization of derelict and mismanaged buildings in rural areas of Lithuania is analyzed. Accordingly, based to the theoretical assumptions and a study of the existing situation as presented in previous papers of the authors (Zavadskas and Antucheviciene, 2006, 2007; Antucheviciene and Zavadskas, 2008), three potential alternative decisions for the regeneration of rural property are suggested and implicated in the future multiple criteria evaluation. The alternatives include reconstruction of rural buildings and adapting them to production (or commercial) activities (alternative $A_{1}$ ), improving and using them for farming (alternative $A_{2}$ ) or dismantling and recycling the demolition waste materials (alternative $A_{3}$ ). Three groups of criteria (indicators) describing the suggested alternatives, were suggested: existing state, development possibilities and impact. All suggested subsystems consisted of a number of indicators and were selected from the available and approved sustainability indicator systems and then adapted to local singularities and to the peculiarities of the problem (see the previous research of the authors: Antucheviciene and Zavadskas, 2008; Zavadskas and Antucheviciene, 2006, 2007).

The following fifteen criteria (or sustainability indicators) in evaluating regeneration alternatives of buildings have been taken into consideration, including the average soil fertility in the area $X_{1}$ (points), quality of life of the local population $X_{2}$ (points), population activity index $X_{3}(\%)$, GDP proportion with respect to the average GDP of the 
country $X_{4}(\%)$, material investment in the area $X_{5}$ (Lt per resident), foreign investments in the area $X_{6}\left(\mathrm{Lt} \times 10^{3}\right.$ per resident), building redevelopment costs $X_{7}\left(\mathrm{Lt} \times 10^{6}\right)$, increase the income of local population $X_{8}\left(\mathrm{Lt} \times 10^{6}\right.$ per year), increase of sales in the area $X_{9}(\%)$, increase of employment in the area $X_{10}(\%)$, state income from business and property taxes $X_{11}$ ( $\mathrm{Lt} \times 10^{6}$ per year), business outlook $X_{12}$, difficulties in changing the original purpose of a site $X_{13}$, degree of contamination $X_{14}$, attractiveness of the countryside (i.e., image, landscape etc) $X_{15}$. The criteria $X_{12}, X_{13}, X_{14}$ and $X_{15}$ are qualitative and expressed by linguistic variables. Among the criteria considered $X_{2}, X_{7}, X_{13}$ and $X_{14}$ are associated with cost/loss and so their lower value is better, while the remaining criteria are associated with benefit and their greater value is better.

The values of the criteria $f_{i j}, i=1, \ldots, m ; j=1, \ldots, n$ are estimated according to official statistical data and on the basis of previous research by the authors. As the crisp data is fuzzyfied at the presented research, the lower and the upper values of a triplet $\left(f_{1_{i j}} ; f_{2_{i j}} ; f_{3_{i j}}\right), i=1, \ldots, m ; j=1, \ldots, n$ of the state criteria are set according to the best and the worst possible values in the area considered, enabling one to determine smaller characteristic segments in the research, while values of the development possibilities and the impact criteria are established by considering the range of buildings to be redeveloped, minimum and maximum cost of alternative solutions' implementation, presumptive limits of possible workplaces and income, possible alterations of landscape quality and environmental contamination. The qualitative attributes $X_{12}, X_{13}, X_{14}$ and $X_{15}$ and their ratings are expressed by linguistic variables, as used in fuzzy decisionmaking. The relations between linguistic variables and triangular fuzzy numbers, used in this paper, are given in Table 1.

Development possibilities and the impact criteria are considered to be of equal importance, while weights are determined for state criteria. The weights $q_{i}, i=1, \ldots, m$; $j=1, \ldots, n$ are determined according to the estimated statistical relations between factors in the course of the correlation analysis (Antucheviciene, 2003).

The data is grouped in three regions according to a concept of spatial development of the country: i.e., areas of active development, areas of regressing development and 'buffer' areas. Matrix of initial data for evaluation of derelict buildings regeneration alternatives in areas of different development activity is presented in Table 2.

\subsection{Ranking Results}

Based on presented initial data (Table 2) and described methodology of the research, six initial fuzzified decision making matrices are formed, i.e., potential redevelopment decisions are evaluated separately in three areas of different development activity as well as two development strategies, as presented in the Master Plan of the Territory Development of the Republic of Lithuania, that refer to the maintenance of the existing economic potential of a region (MEP) and the harmonization of regional development (HRD), are considered. Strategies presented in the Master Plan, and are evaluated in linguistic terms as well as expressed by fuzzy triangular numbers (Zavadskas and Antucheviciene, 2007).

After the initial data is prepared, calculations are performed using above (Section 2) described and fuzzified MCDM methods and applying calculation algorithms accord- 
Table 2

Initial data for derelict buildings regeneration

\begin{tabular}{|c|c|c|c|}
\hline \multirow[t]{2}{*}{ Criteria } & \multicolumn{3}{|c|}{ Value of criteria $\left(f_{i j_{1}} ; f_{i j_{2}} ; f_{i j_{3}}\right)$} \\
\hline & Alternative $A_{1}$ & Alternative $A_{2}$ & Alternative $A_{3}$ \\
\hline \multicolumn{4}{|c|}{ Areas of active development } \\
\hline$X_{1}$ & $(30.9 ; 39.9 ; 50.0)$ & $(30.9 ; 39.9 ; 50.0)$ & $(30.9 ; 39.9 ; 50.0)$ \\
\hline$X_{2}$ & $(39.3 ; 31.7 ; 23.1)$ & $(39.3 ; 31.7 ; 23.1)$ & $(39.3 ; 31.7 ; 23.1)$ \\
\hline$X_{3}$ & $(39.8 ; 51.7 ; 68.1)$ & $(39.8 ; 51.7 ; 68.1)$ & $(39.8 ; 51.7 ; 68.1)$ \\
\hline$X_{4}$ & $(73.9 ; 98.4 ; 137.3)$ & $(73.9 ; 98.4 ; 137.3)$ & $(73.9 ; 98.4 ; 137.3)$ \\
\hline$X_{5}$ & $(552.0 ; 1304.0 ; 3561.0)$ & $(552.0 ; 1304.0 ; 3561.0)$ & $(552.0 ; 1304.0 ; 3561.0)$ \\
\hline$X_{6}$ & $(73.2 ; 1028.7 ; 4160.0)$ & $(73.2 ; 1028.7 ; 4160.0)$ & $(73.2 ; 1028.7 ; 4160.0)$ \\
\hline$X_{7}$ & $(766.1 ; 273.6 ; 35.6)$ & $(144.9 ; 59.4 ; 28.5)$ & $(20.2 ; 14.4 ; 8.6)$ \\
\hline$X_{8}$ & $(31.1 ; 69.1 ; 241.9)$ & $(7.8 ; 25.9 ; 48.4)$ & $(0.3 ; 0.4 ; 1.2)$ \\
\hline$X_{9}$ & $(2.3 ; 14.0 ; 39.1)$ & $(0.7 ; 2.2 ; 4.7)$ & $(0 ; 0 ; 0)$ \\
\hline$X_{10}$ & $(2.1 ; 3.4 ; 9.6)$ & $(0.5 ; 1.7 ; 2.4)$ & $(0 ; 0 ; 0)$ \\
\hline$X_{11}$ & $(8.6 ; 21.6 ; 50.4)$ & $(2.2 ; 5.4 ; 10.1)$ & $(0.1 ; 0.2 ; 0.5)$ \\
\hline$X_{12}$ & $(0.8 ; 0.9 ; 1)$ & $(0.2 ; 0.3 ; 0.4)$ & $(0.6 ; 0.7 ; 0.8)$ \\
\hline$X_{13}$ & $(0.8 ; 0.9 ; 1)$ & $(0 ; 0.1 ; 0.2)$ & $(0.6 ; 0.7 ; 0.8)$ \\
\hline$X_{14}$ & $(0.6 ; 0.7 ; 0.8)$ & $(0.4 ; 0.5 ; 0.6)$ & $(0 ; 0.1 ; 0.2)$ \\
\hline$X_{15}$ & $(0.6 ; 0.7 ; 0.8)$ & $(0.4 ; 0.5 ; 0.6)$ & $(0.2 ; 0.3 ; 0.4)$ \\
\hline \multicolumn{4}{|c|}{ Areas of regressing development } \\
\hline$X_{1}$ & $(31.1 ; 34.8 ; 44.3)$ & $(31.1 ; 34.8 ; 44.3)$ & $(31.1 ; 34.8 ; 44.3)$ \\
\hline$X_{2}$ & $(37.78 ; 29.1 ; 20.78)$ & $(37.78 ; 29.1 ; 20.78)$ & $(37.78 ; 29.1 ; 20.78)$ \\
\hline$X_{3}$ & $(47.1 ; 55.9 ; 66.2)$ & $(47.1 ; 55.9 ; 66.2)$ & $(47.1 ; 55.9 ; 66.2)$ \\
\hline$X_{4}$ & $(79.5 ; 94.7 ; 137.3)$ & $(79.5 ; 94.7 ; 137.3)$ & $(79.5 ; 94.7 ; 137.3)$ \\
\hline$X_{5}$ & $(212.0 ; 962.9 ; 3504.0)$ & $(212.0 ; 962.9 ; 3504.0)$ & $(212.0 ; 962.9 ; 3504.0)$ \\
\hline$X_{6}$ & $(8.14 ; 833.1 ; 3550.5)$ & $(8.14 ; 833.1 ; 3550.5)$ & $(8.14 ; 833.1 ; 3550.5)$ \\
\hline$X_{7}$ & $(667.3 ; 238.6 ; 31.0)$ & $(100.1 ; 51.8 ; 24.8)$ & $(17.6 ; 12.6 ; 7.6)$ \\
\hline$X_{8}$ & $(27.1 ; 60.3 ; 210.7)$ & $(6.8 ; 22.6 ; 42.1)$ & $(0.2 ; 0.4 ; 1.1)$ \\
\hline$X_{9}$ & $(12.7 ; 75.8 ; 212.1)$ & $(3.6 ; 12.1 ; 25.4)$ & $(0 ; 0 ; 0)$ \\
\hline$X_{10}$ & $(1.6 ; 2.6 ; 7.3)$ & $(0.4 ; 1.3 ; 1.8)$ & $(0 ; 0 ; 0)$ \\
\hline$X_{11}$ & $(7.5 ; 22.0 ; 43.9)$ & $(1.9 ; 4.7 ; 8.8)$ & $(0.1 ; 0.2 ; 0.4)$ \\
\hline$X_{12}$ & $(0.2 ; 0.3 ; 0.4)$ & $(0.4 ; 0.5 ; 0.6)$ & $(0 ; 0.1 ; 0.2)$ \\
\hline$X_{13}$ & $(0.4 ; 0.5 ; 0.6)$ & $(0 ; 0.1 ; 0.2)$ & $(0 ; 0.1 ; 0.2)$ \\
\hline$X_{14}$ & $(0.4 ; 0.5 ; 0.6)$ & $(0 ; 0.1 ; 0.2)$ & $(0 ; 0.1 ; 0.2)$ \\
\hline$X_{15}$ & $(0.6 ; 0.7 ; 0.8)$ & $(0.6 ; 0.7 ; 0.8)$ & $(0.4 ; 0.5 ; 0.6)$ \\
\hline \multicolumn{4}{|c|}{ 'Buffer' areas } \\
\hline$X_{1}$ & $(30.4 ; 40.0 ; 48.2)$ & $(30.4 ; 40.0 ; 48.2)$ & $(30.4 ; 40.0 ; 48.2)$ \\
\hline$X_{2}$ & $(32.9 ; 30.3 ; 26.8)$ & $(32.9 ; 30.3 ; 26.8)$ & $(32.9 ; 30.3 ; 26.8)$ \\
\hline$X_{3}$ & $(47.3 ; 55.8 ; 61.2)$ & $(47.3 ; 55.8 ; 61.2)$ & $(47.3 ; 55.8 ; 61.2)$ \\
\hline$X_{4}$ & $(59.9 ; 78.1 ; 97.8)$ & $(59.9 ; 78.1 ; 97.8)$ & $(59.9 ; 78.1 ; 97.8)$ \\
\hline$X_{5}$ & $(356.5 ; 663.5 ; 1398.6)$ & $(356.5 ; 663.5 ; 1398.6)$ & $(356.5 ; 663.5 ; 1398.6)$ \\
\hline$X_{6}$ & $(0.41 ; 244.0 ; 607.8)$ & $(0.41 ; 244.0 ; 607.8)$ & $(0.41 ; 244.0 ; 607.8)$ \\
\hline$X_{7}$ & $(808.6 ; 288.8 ; 37.6)$ & $(121.3 ; 62.7 ; 30.1)$ & $(21.3 ; 15.2 ; 9.1)$ \\
\hline$X_{8}$ & $(32.8 ; 73.0 ; 255.4)$ & $(8.2 ; 27.4 ; 51.1)$ & $(0.3 ; 0.5 ; 1.3)$ \\
\hline$X_{9}$ & $(14.4 ; 85.5 ; 239.3)$ & $(4.1 ; 13.7 ; 28.7)$ & $(0 ; 0 ; 0)$ \\
\hline$X_{10}$ & $(23.0 ; 3.8 ; 10.6)$ & $(0.6 ; 1.9 ; 2.7)$ & $(0 ; 0 ; 0)$ \\
\hline$X_{11}$ & $(9.1 ; 26.6 ; 53.2)$ & $(2.3 ; 5.7 ; 10.6)$ & $(0.1 ; 0.2 ; 0.5)$ \\
\hline$X_{12}$ & $(0.4 ; 0.5 ; 0.6)$ & $(0.2 ; 0.3 ; 0.4)$ & $(0.2 ; 0.3 ; 0.4)$ \\
\hline$X_{13}$ & $(0.8 ; 0.9 ; 1)$ & $(0 ; 0.1 ; 0.2)$ & $(0.4 ; 0.5 ; 0.6)$ \\
\hline$X_{14}$ & $(0.2 ; 0.3 ; 0.4)$ & $(0 ; 0.1 ; 0.2)$ & $(0 ; 0.1 ; 0.2)$ \\
\hline$X_{15}$ & $(0.8 ; 0.9 ; 1)$ & $(0.4 ; 0.5 ; 0.6)$ & $(0.8 ; 0.9 ; 1)$ \\
\hline
\end{tabular}


ing to (1)-(22). Potential redevelopment variants of derelict buildings are evaluated applying fuzzified COPRAS, TOPSIS based on vector as well as linear normalization of initial criteria values and VIKOR methods. Relative significances of alternatives $\left(Q_{j_{1}} ; Q_{j_{2}} ; Q_{j_{3}}\right), j=1, \ldots, n$ (see (4), (12), (16)) and defuzzified values $Q_{j}, j=$ $1, \ldots, n(22)$ are calculated, and priority order of evaluated alternatives is established.

An example of described calculations is presented. Weighted normalised fuzzy decision-making matrix in areas of active development after the implementation of the first strategy (maintenance of the existing potential of a region) and the results of multicriteria analysis applying COPRAS method are presented in Tables 3 and 4.

The other twenty three weighted normalised fuzzy decision matrices are composed in a similar way as the presented one in Table 3. The relative significances as well as priorities of rural buildings redevelopment alternatives are determined by applying the described multiple criteria decision making methods and using adequate operations on fuzzy triangular numbers. Partial results of ranking building redevelopment alternatives applying particular multiple criteria decision making methods were published in previous papers of the authors (Zavadskas and Antucheviciene, 2006, 2007; Antucheviciene and Zavadskas, 2008). Final multiple criteria analysis results obtained for Lithuanian derelict rural building regeneration alternatives in areas of diverse development activities after the implementation of two main strategies for the regional policy and applying particular MCDM methods are presented in Table 5.

Table 3

Weighted normalised fuzzy decision matrix in areas of active development after implementation of the strategy of maintenance of existing potential in a region

\begin{tabular}{llll}
\hline \multirow{2}{*}{ Criteria } & \multicolumn{2}{l}{ Numerical value of weighted normalised criteria $\left(w_{i j_{1}} ; w_{i j_{2}} ; w_{i j_{3}}\right)$} \\
\cline { 2 - 4 } & Alternative $A_{1}$ & Alternative $A_{2}$ & Alternative $A_{3}$ \\
\hline$X_{1}$ & $(0.0343 ; 0.0318 ; 0.0300)$ & $(0.0171 ; 0.0176 ; 0.0180)$ & $(0.0086 ; 0.0106 ; 0.0120)$ \\
$X_{2}$ & $(0.0363 ; 0.0385 ; 0.0415)$ & $(0.0218 ; 0.0214 ; 0.0208)$ & $(0.0145 ; 0.0128 ; 0.0104)$ \\
$X_{3}$ & $(0.0427 ; 0.0395 ; 0.0373)$ & $(0.0213 ; 0.0220 ; 0.0224)$ & $(0.0107 ; 0.0132 ; 0.0149)$ \\
$X_{4}$ & $(0.0358 ; 0.0332 ; 0.0313)$ & $(0.0179 ; 0.0184 ; 0.0188)$ & $(0.0090 ; 0.0111 ; 0.0125)$ \\
$X_{5}$ & $(0.0385 ; 0.0356 ; 0.0337)$ & $(0.0192 ; 0.0198 ; 0.0202)$ & $(0.0096 ; 0.0119 ; 0.0135)$ \\
$X_{6}$ & $(0.0358 ; 0.0332 ; 0.0313)$ & $(0.0179 ; 0.0184 ; 0.0188)$ & $(0.0090 ; 0.0111 ; 0.0125)$ \\
$X_{7}$ & $(0.0593 ; 0.0586 ; 0.0456)$ & $(0.0067 ; 0.0071 ; 0.0183)$ & $(0.0006 ; 0.0010 ; 0.0028)$ \\
$X_{8}$ & $(0.0591 ; 0.0551 ; 0.0594)$ & $(0.0074 ; 0.0115 ; 0.0071)$ & $(0.0001 ; 0.0001 ; 0.0001)$ \\
$X_{9}$ & $(0.0579 ; 0.0613 ; 0.0622)$ & $(0.0088 ; 0.0054 ; 0.0045)$ & $(0.0000 ; 0.0000 ; 0.0000)$ \\
$X_{10}$ & $(0.0596 ; 0.0522 ; 0.0580)$ & $(0.0071 ; 0.0145 ; 0.0087)$ & $(0.0000 ; 0.0000 ; 0.0000)$ \\
$X_{11}$ & $(0.0590 ; 0.0584 ; 0.0593)$ & $(0.0075 ; 0.0081 ; 0.0071)$ & $(0.0002 ; 0.0002 ; 0.0002)$ \\
$X_{12}$ & $(0.0508 ; 0.0462 ; 0.0427)$ & $(0.0063 ; 0.0085 ; 0.0103)$ & $(0.0095 ; 0.0120 ; 0.0137)$ \\
$X_{13}$ & $(0.0463 ; 0.0505 ; 0.0561)$ & $(0.0056 ; 0.0031 ; 0.0000)$ & $(0.0148 ; 0.0131 ; 0.0105)$ \\
$X_{14}$ & $(0.0430 ; 0.0462 ; 0.0500)$ & $(0.0194 ; 0.0183 ; 0.0167)$ & $(0.0043 ; 0.0022 ; 0.0000)$ \\
$X_{15}$ & $(0.0471 ; 0.0433 ; 0.0404)$ & $(0.0157 ; 0.0172 ; 0.0182)$ & $(0.0039 ; 0.0062 ; 0.0081)$
\end{tabular}


Table 4

Analysis results applying COPRAS method in areas of active development after implementation of the strategy of maintenance of existing potential in a region

\begin{tabular}{llll}
\hline Variables & \multicolumn{2}{l}{ Numerical values } & \\
\cline { 2 - 4 } & Alternative $A_{1}$ & Alternative $A_{2}$ & Alternative $A_{3}$ \\
\hline $\begin{array}{l}\text { Total maximising } \\
\text { values }\left(S_{j 1}^{*} ; S_{j 2}^{*} ; S_{j 3}^{*}\right)\end{array}$ & $(0.5204 ; 0.4897 ; 0.4857)$ & $(0.1464 ; 0.1614 ; 0.1541)$ & $(0.0605 ; 0.0762 ; 0.0876)$ \\
$\begin{array}{l}\text { Total minimising } \\
\text { values }\left(S_{j 1}^{-} ; S_{j 2}^{-} ; S_{j 3}^{-}\right)\end{array}$ & $(0.1850 ; 0.1937 ; 0.1933)$ & $(0.0534 ; 0.0499 ; 0.0557)$ & $(0.0343 ; 0.0291 ; 0.0237)$ \\
$\begin{array}{l}\text { Relative significance } \\
\left(Q_{j 1} ; Q_{j 2} ; Q_{j 3}\right)\end{array}$ & $(0.5481 ; 0.5133 ; 0.5073)$ & $(0.2421 ; 0.2533 ; 0.2290)$ & $(0.2098 ; 0.2334 ; 0.2638)$ \\
$\begin{array}{l}\text { Defuzzified } \\
\text { significance } Q_{j}\end{array}$ & 0.5229 & & \\
Priority order & 1 & 0.2415 & 0.2357 \\
\hline
\end{tabular}

\section{Measuring Congruence (Incongruence) of Ranking Results}

According to calculation results as presented in Table 6 we can formulate six conclusions concerning rural building redevelopment in Lithuania, i.e., different recommendations can be made in three areas of particular development activity and applying two redevelopment strategies in every area. However, when analysing multiple criteria evaluation of alternatives, one can observe that relative significances of alternatives and some time even the priority order of redevelopment alternatives differs when several MCDM methods are applied. The aim of the presented case study is to determine priorities as well as to produce some recommendations concerning rational redevelopment of buildings. For the above reason particular relative significances of alternatives $Q_{j}, j=1, \ldots, n$ are not analyzed in detail. The main attention is paid to priority order of alternatives, established by applying different MCDM methods.

Correlation coefficients are calculated and objective congruence (incongruence) of ranks that were computed by using different MCDM methods is measured. In order to increase the reliability of correlation analysis, 234 experimental variants of building redevelopment initial decision making matrixes are composed (replacing values of criteria, relative significances of criteria, relative significances of redevelopment strategies). Multiple criteria analysis of described experimental variants is performed applying all analyzed methods (COPRAS, TOPSIS based on vector as well as linear normalization of initial criteria values and VIKOR). Calculation results are compared.

Method of non-parametrical correlation is applied to measure statistical relation of ranks of alternatives that were computed by using different MCDM methods (Deng et al., 2000; Yurdakul and Ic, 2009; Raju and Kumar, 2010). Using Spearman's correlation coefficient relations are calculated not among values of variables themselves, but among 
Table 5

Results of multiple criteria analysis

\begin{tabular}{|c|c|c|c|c|c|c|}
\hline \multirow[t]{2}{*}{$\begin{array}{l}\text { MCDM } \\
\text { method }\end{array}$} & \multirow[t]{2}{*}{ Area } & \multirow[t]{2}{*}{ Strategy } & \multicolumn{3}{|c|}{$\begin{array}{l}\text { Significance of } \\
\text { alternatives } Q_{j}\end{array}$} & \multirow[t]{2}{*}{$\begin{array}{l}\text { Priority } \\
\text { order }\end{array}$} \\
\hline & & & $\overline{A_{1}}$ & $A_{2}$ & $A_{3}$ & \\
\hline \multirow[t]{6}{*}{ COPRAS } & \multirow[t]{2}{*}{ Active development } & MEP* & 0.52 & 0.24 & 0.23 & $A_{1} \succ A_{2} \approx A_{3}$ \\
\hline & & $\mathrm{HRD}^{* *}$ & 0.35 & 0.36 & 0.29 & $A_{2} \approx A_{1} \succ A_{3}$ \\
\hline & \multirow[t]{2}{*}{ Regressing development } & MEP* & 0.28 & 0.44 & 0.29 & $A_{2} \succ A_{3} \approx A_{1}$ \\
\hline & & HRD** & 0.50 & 0.26 & 0.24 & $A_{1} \succ A_{2} \approx A_{3}$ \\
\hline & \multirow[t]{2}{*}{ 'Buffer' } & MEP* & 0.44 & 0.31 & 0.24 & $A_{1} \succ A_{2} \succ \mathrm{A}_{3}$ \\
\hline & & HRD** & 0.45 & 0.31 & 0.24 & $A_{1} \succ A_{2} \succ A_{3}$ \\
\hline \multirow{6}{*}{$\begin{array}{l}\text { TOPSIS } \\
\text { based on vector } \\
\text { normalization }\end{array}$} & \multirow[t]{2}{*}{ Active development } & MEP* & 0.61 & 0.41 & 0.36 & $A_{1} \succ A_{2} \succ A_{3}$ \\
\hline & & HRD** & 0.53 & 0.49 & 0.36 & $A_{1} \succ A_{2} \succ A_{3}$ \\
\hline & \multirow[t]{2}{*}{ Regressing development } & MEP* & 0.50 & 0.56 & 0.46 & $A_{2} \succ A_{1} \succ A_{3}$ \\
\hline & & HRD** & 0.61 & 0.45 & 0.46 & $A_{1} \succ A_{3} \approx A_{2}$ \\
\hline & \multirow[t]{2}{*}{ 'Buffer' } & MEP* & 0.59 & 0.43 & 0.38 & $A_{1} \succ A_{2} \succ A_{3}$ \\
\hline & & $\mathrm{HRD}^{* *}$ & 0.61 & 0.47 & 0.36 & $A_{1} \succ A_{2} \succ A_{3}$ \\
\hline \multirow{6}{*}{$\begin{array}{l}\text { TOPSIS } \\
\text { based on linear } \\
\text { normalization }\end{array}$} & \multirow[t]{2}{*}{ Active development } & MEP* & 0.62 & 0.42 & 0.37 & $A_{1} \succ A_{2} \succ A_{3}$ \\
\hline & & HRD** & 0.49 & 0.54 & 0.37 & $A_{2} \succ A_{1} \succ A_{3}$ \\
\hline & \multirow[t]{2}{*}{ Regressing development } & MEP* & 0.46 & 0.64 & 0.48 & $A_{2} \succ A_{3} \approx A_{1}$ \\
\hline & & HRD** & 0.62 & 0.46 & 0.48 & $A_{1} \succ A_{3} \approx A_{2}$ \\
\hline & \multirow[t]{2}{*}{ 'Buffer' } & MEP* & 0.47 & 0.37 & 0.53 & $A_{3} \succ A_{1} \succ A_{2}$ \\
\hline & & $\mathrm{HRD}^{* *}$ & 0.64 & 0.55 & 0.35 & $A_{1} \succ A_{2} \succ A_{3}$ \\
\hline \multirow[t]{6}{*}{ VIKOR } & \multirow[t]{2}{*}{ Active development } & MEP* & 0.38 & 0.36 & 1.00 & $A_{2} \approx A_{1} \succ A_{3}$ \\
\hline & & HRD** & 0.65 & 0.00 & 1.00 & $A_{2} \succ A_{1} \succ A_{3}$ \\
\hline & \multirow[t]{2}{*}{ Regressing development } & MEP* & 1.00 & 0.00 & 0.64 & $A_{2} \succ A_{3} \succ A_{1}$ \\
\hline & & HRD** & 0.00 & 1.00 & 0.45 & $A_{1} \succ A_{3} \succ A_{2}$ \\
\hline & \multirow[t]{2}{*}{ 'Buffer' } & MEP* & 0.67 & 1.00 & 0.00 & $A_{3} \succ A_{1} \succ A_{2}$ \\
\hline & & HRD** & 0.00 & 0.17 & 1.00 & $A_{1} \succ A_{2} \succ A_{3}$ \\
\hline
\end{tabular}

* Maintenance of existing economic potential in a region.

** Harmonization of regional development.

ranks of variables. The current coefficient best fits the aim of the presented research, because the aim of this research is to compare priorities (ranks) of alternative decisions obtained in a process of multiple criteria analysis when applying different MCDM methods. Accordingly, Spearman's rank correlation coefficients $r_{s}$ and confidence intervals of correlation coefficients with the probability $p=1-q=0.95$ are calculated (Aivazian and Mkhitarian, 1998).

Spearman's rank correlation coefficients are calculated for the ranks provided by every possible pairs of the applied multiple criteria decision making algorithms. It is found that all correlation coefficients are statistically significant with the probability of 95 percent. 


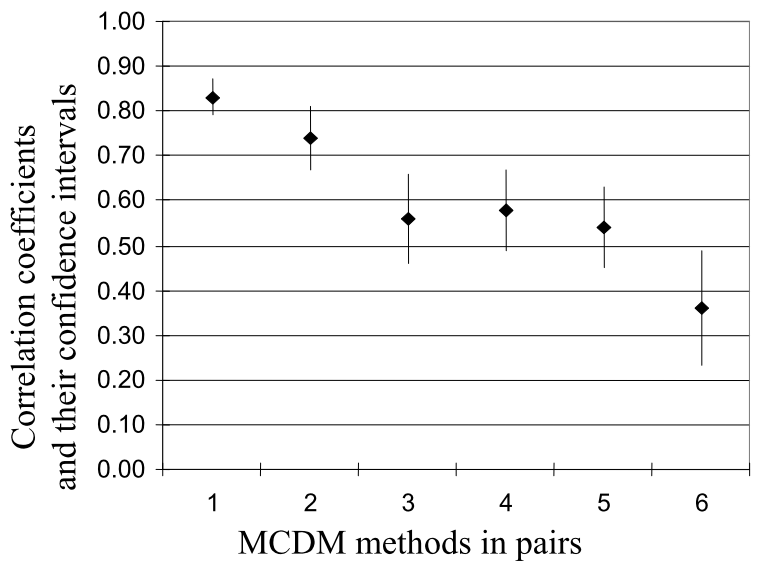

Fig. 1. Spearman's rank correlation coefficients and confidence intervals: 1-6 - Spearman's rank correlation coefficients between results of two multiple criteria decision making methods ( 1 - TOPSIS, applying vector normalization and TOPSIS, applying linear normalization; 2 - TOPSIS, linear normalization and VIKOR; 3 TOPSIS, vector normalization, and VIKOR; 4 - TOPSIS, vector normalization, and COPRAS; 5 - TOPSIS, linear normalization, and COPRAS; 6 - COPRAS and VIKOR); - rank correlation coefficient; | - confidence interval of rank correlation coefficient with the reliability level $q=0.05$.

Accordingly, we can state that the ranks in the every pair of compared methods have statistically significant relations and results of comparison are statistically reliable.

Empirical Pirson's correlation coefficients of particular comparative variants are calculated in order to check the results. Incongruence of empirical correlation coefficients and Spearman's rank correlation coefficients is not higher than 10 percents in all analyzed cases. The average incongruence is 4 percent.

Confidence intervals of correlation coefficients with the reliability level $q=0.05$ are calculated. Calculation results are presented in Fig. 1.

In Fig. 1 we can observe that some of the results have higher rank correlation relationship and some have the lower one when a particular pairs of multiple criteria decision making methods are analyzed.

Priorities of alternatives, computed by TOPSIS method, applying vector as well as linear normalization methods to eliminate the units of the criteria values, provide the strongest statistical relations. However, the results are not identical and congruence of 100 percent is not observed. The value of Spearman's rank correlation coefficient is high enough (0.83) and is statistically significant, but not equals to 1 . Consequently, experimental calculations prove the theoretical presumption that normalization methods applied to eliminate the units of the criteria values influence the final ranking results.

TOPSIS and COPRAS ranking results also have significant relations. Correlation coefficients are 0.58 and 0.54 , applying vector and linear normalization in TOPSIS, respectively.

The lowest correlation relation is established when congruence (incongruence) of COPRAS and VIKOR methods is analyzed. Estimated Spearman's rank correlation coefficient is 0.36 . 
The above Spearman's rank correlation coefficients are calculated with a particular level of reliability. We can state that the real values of Spearman's rank correlation coefficients are within the limits of confidence intervals with the probability $p=1-q$. In Fig. 1 we can observe that the major parts of confidence intervals overlap. Then the question arises if rank correlation coefficients of particular pairs of MCDM methods are really different. Are the calculated differences significant? The above dilemma is solved by the authors not by subjective evaluation but applying methods of mathematical statistics as presented further in the paper.

Statistical identity (or nonidentity) of values of correlation coefficients, calculated for $N_{1}, N_{2}, \ldots, N_{s}$ samples of data pairs, is checked not only based on confidence intervals, but also applying statistics $V$ (Aivazian and Mkhitarian, 1998). Hypothesis that all correlation coefficients, calculated for particular samples of data pairs, are identical with the probability $p=1-q$ (i.e., calculated incongruence is within the limits of random errors) can be accepted in a case if

$$
V \leqslant \chi_{k, q}^{2}
$$

where $\chi_{k, q}^{2}$ - Pirson's distribution with the reliability $q$ and $k=s-1$ degrees of freedom, where $s$-number of compared correlation coefficients.

Fisher's transformation $z$ and overall Fisher's transformation of correlation set $\bar{z}$ is calculated (Aivazian and Mkhitarian, 1998). Value $r$ of correlation coefficient generalized for all correlation set is calculated in the research.

First of all, Spearman's rank correlation coefficients as calculated for six pairs of data samples are compared, i.e., $r_{1}$ - TOPSIS, applying vector normalization, and TOPSIS, applying linear normalization; $r_{2}$ - TOPSIS, linear normalization, and VIKOR; $r_{3}$ - TOPSIS, vector normalization, and VIKOR; $r_{4}$ - TOPSIS, vector normalization, and COPRAS; $r_{5}$ - TOPSIS, linear normalization, and COPRAS; $r_{6}$ - COPRAS and VIKOR.

Hypothesis that all six correlation coefficients are identical, i.e., calculated incongruence is within the limits of random errors, is not accepted after calculations, because requirement according to (23) is not fulfilled.

As the primary hypothesis was not accepted, the research is proceeded by variously grouping calculated correlation coefficients and verifying the hypothesis. The main results of the current research are presented in Table 6.

First of all, correlation coefficient with the lower value is eliminated, showing connections between VIKOR and TOPSIS results. Correlation coefficient for an entire set slightly increases (from 0.63 to 0.67 ), but the hypothesis is still unaccepted.

Then the authors intended to eliminate the results of evaluation of derelict rural buildings redevelopment alternatives applying VIKOR method. Therefore all coefficients describing relations with VIKOR results are rejected in the next step of calculation. But any positive effect is observed. Correlation coefficient for an entire set remains the same (0.67).

Connections of COPRAS results with the results of other analyzed methods are checked in the next step. For that reason calculations are performed using all correlation coefficients showing statistical connections between COPRAS and the other three 


\section{Table 6}

Verification of hypothesis regarding incongruence of correlation coefficients (within the reliability level $q=0.05)$. Estimation of correlation coefficient generalized for an entire correlation set

\begin{tabular}{lllll}
\hline $\begin{array}{l}\text { Correlation } \\
\text { coefficients } r_{i}\end{array}$ & $\begin{array}{l}\text { Values of } \\
\text { coefficients }\end{array}$ & $\begin{array}{l}\text { Statistics } \\
V\end{array}$ & $\begin{array}{l}\chi_{k, q}^{2} \\
\text { Correlation coefficient }\end{array}$ \\
\hline$r_{1}$ & 0.83 & 85.77 & 11.07 & 0.63 \\
$r_{2}$ & 0.74 & & & \\
$r_{3}$ & 0.56 & & & \\
$r_{4}$ & 0.58 & & & \\
$r_{5}$ & 0.54 & & & \\
$r_{6}$ & 0.36 & & & \\
$r_{1}$ & 0.83 & 57.05 & 9.48 & 0.67 \\
$r_{2}$ & 0.74 & & & \\
$r_{3}$ & 0.56 & & & \\
$r_{4}$ & 0.58 & & & \\
$r_{5}$ & 0.54 & & & \\
$r_{1}$ & 0.83 & 47.80 & 5.99 & 0.67 \\
$r_{4}$ & 0.58 & & & \\
$r_{5}$ & 0.54 & & & \\
$r_{4}$ & 0.58 & 8.91 & 5.99 & 0.51 \\
$r_{5}$ & 0.54 & & & \\
$r_{6}$ & 0.36 & & & \\
$r_{4}$ & 0.58 & 0.39 & 3.84 & 0.56 \\
$r_{5}$ & 0.54 & & & \\
$r_{1}$ & 0.83 & 31.20 & 5.99 & 0.74 \\
$r_{2}$ & 0.74 & & & \\
$r_{3}$ & 0.56 & & & \\
\hline
\end{tabular}

methods (TOPSIS with vector as well as linear normalization and VIKOR). We can state that correlation coefficients are still different with the reliability level $q=0.05$.

In a case when VIKOR method is eliminated, the hypothesis concerning congruence of Spearman's rank correlation coefficients between COPRAS and TOPSIS results is accepted with the reliability level $q=0.05$.

Also an attempt to eliminate COPRAS method is made. Spearman's rank correlation coefficients between ranks in TOPSIS and VIKOR methods are compared. Unfortunately, the hypothesis concerning congruence of coefficients is not accepted.

The general conclusion based on the research is that Spearman's rank correlation coefficients between ranking results of alternatives applying COPRAS and TOPSIS methods (using vector as well as linear criteria values normalization) can be considered to be identical with the probability $p \geqslant 0.95$. Ranking results of the particular methods can be considered to be congruous with the same probability. 


\section{Conclusions}

Ranking of building redevelopment alternatives was performed by using fuzzified COPRAS, TOPSIS that applied vector and linear criteria normalization and VIKOR multiple-criteria decision making methods. It was found that the priority order of the redevelopment alternatives of buildings was not always the same in a particular region.

Spearman's rank correlation coefficients were calculated to measure objective congruence (incongruence) of ranks of derelict buildings' management alternatives. It was found that every correlation coefficient was statistically significant with the probability of 95 percent and experimental results were statistically reliable.

It was found that Spearman's rank correlation coefficients between the COPRAS and the TOPSIS (using vector as well as linear criteria values normalization) methods can be considered congruous within the probability of $p \geqslant 0.95$. Accordingly, multiple criteria evaluation results applying COPRAS and TOPSIS methods can be considered to be identical within the same probability. It was proved that the final decision should be adopted by giving the priority to the results of COPRAS and TOPSIS methods instead of VIKOR, if the ranking results of the analyzed methods differ.

\section{References}

Aivazian, S.A., Mkhitarian, V.S. (1998). Applied Statistics and Essentials of Econometrics, Junity, Moscow (in Russian).

Amiri, M.P. (2010). Project selection for oil-fields development by using the AHP and fuzzy TOPSIS methods. Expert Systems with Applications, 37(9), 6218-6224.

Antucheviciene, J. (2003). Principles of revitalization of derelict rural buildings. Journal of Civil Engineering and Management, 9(4), 225-233.

Antucheviciene, J., Zavadskas, E.K. (2008). Modelling multidimensional redevelopment of derelict buildings. International Journal of Environment and Pollution, 35(2/3/4), 331-344.

Antucheviciene, J., Zavadskas, E.K., Zakarevicius, A. (2010). Multiple criteria construction management decisions considering relations between criteria. Technological and Economic Development of Economy, 16(1), $109-125$.

Bindu Madhuri, Ch., Anand Chandulal, J. (2010). Evaluating web sites using COPRAS-GRA combined with grey clustering. International Journal of Engineering Science and Technology, 2(10), 5280-5294.

Bindu Madhuri, Ch., Anand Chandulal, J., Padmaja, M. (2010). Selection of best web site by applying COPRAS-G method. International Journal of Computer Science and Information Technologies, 1(2), 138146.

Boran, F.E., Genç, S., Kurt, M., Akay, D. (2009). A multi-criteria intuitionistic fuzzy group decision making for supplier selection with TOPSIS method. Expert Systems with Applications, 36(8), 11363-11368.

Chang, Ch. H., Lin, J.J., Lin, J.H., Chiang, M.Ch. (2010). Domestic open-end equity mutual fund performance evaluation using extended TOPSIS method with different distance approaches. Expert Systems with Applications, 37(6), 4642-4649.

Chatterjee, P., Athawale, V.M., Chakraborty, S. (2011). Materials selection using complex proportional assessment and evaluation of mixed data methods. Materials \& Design, 32(2), 851-860.

Deng, H., Yeh, Ch.H., Willis, R.J. (2000). Inter-company comparison using modified TOPSIS with objective weights. Computers and Operations Research, 27, 963-973.

Ginevicius, R., Podvezko, V. (2009). Evaluating the changes in economic and social development of Lithuanian countries by multiple criteria methods. Technological and Economic Development of Economy, 15(3), 418436 . 
Ginevicius, R., Zubrecovas, V. (2009). Selection of the optimal real estate investment project basing on multiple criteria evaluation using stochastic dimensions. Journal of Business Economics and Management, 10(3), 261-270.

Ginevicius, R., Krivka, A., Simkunaite, J. (2010). The model of forming competitive strategy of an enterprise under the conditions of oligopolic market. Journal of Business Economic and Management, 11(3), 367-395.

Hajkowicz, S., Higgins, A. (2008). A comparison of multiple criteria analysis techniques for water resource management. European Journal of Operational Research, 184(1), 255-265.

Hwang, C.L., Yoon, K. (1981). Multiple Attribute Decision Making Methods and Applications. Springer, Berlin.

Ic, Y.T., Yurdakul, M. (2010). Development of a quick reliability scoring decision support system using fuzzy TOPSIS. Expert Systems with Applications, 37(1), 567-574.

Jakimavicius, M., Burinskiene, M. (2009). A GIS and multi-criteria-based analysis and ranking of transportation zones of Vilnius city. Technological and Economic Development of Economy, 15(1), 39-48.

Kalibatas, D., Zavadskas, E.K., Kalibatiene, D. (2011). The concept of the ideal indoor environment in multiattribute assessment of dwelling-houses. Archives of Civil and Mechanical Engineering, 11(1), 89-101.

Kucas, A. (2010). Location prioritization by means of multicriteria spatial decision-support systems: a case study of forest fragmentation-based ranking of forest administrative areas. Journal of Environmental Engineering and Landscape Management, 18(4), 312-320.

Lai, Y.J., Hwang, C.L. (1994). Fuzzy Multiple Objective Decision Making: Methods and Applications. Springer, Berlin.

Liaudanskiene, R., Ustinovicius, L., Bogdanovicius, A. (2009). Evaluation of construction process safety solutions using the TOPSIS method. Inzinerine Ekonomika - Engineering Economics, (4), 32-40.

Liu, P. (2009). Multi-attribute decision-making method research based on interval vague set and TOPSIS method. Technological and Economic Development of Economy, 15(3), 453-463.

Marzouk, M. (2008). A superiority and inferiority ranking model for contractor selection. Construction Innovation: Information, Process, Management, 8(4), 250-268.

Mazumdar, A., Datta, S., Mahapatra, S.S. (2010). Multicriteria decision-making models for the evaluation and appraisal of teacher' performance. International Journal of Productity and Quality Management, 6(2), 213230.

Opricovic, S. (1998). Multi-Criteria Optimization of Civil Engineering Systems. Faculty of Civil Engineering, Belgrade.

Opricivic, S. (2007). A fuzzy compromise solution for multicriteria problems. International Journal of Uncertainty, Fuzziness and Knowledge-Based Systems, 15(3), 363-380.

Opricovic, S., Tzeng, G.H. (2004). Compromise solution by MCDM methods: a comparative analysis of VIKOR and TOPSIS, European Journal of Operational Research, 156(2), 445-455.

Podvezko, V. (2011). The comparative analysis of MCDA methods SAW and COPRAS. Inzinerine Ekonomika - Engineering Economics, 22(2), 134-146.

Podvezko, V., Mitkus, S., Trinkuniene, E. (2010). Complex evaluation of contracts for construction. Journal of Civil Engineering and Management, 16(2), 287-297.

Raju, K.S., Kumar, D.N. (2010). Multicriterion Analysis in Engineering and Management, Raj Press, New Delhi.

Saremi, M., Mousavi, S.F., Sanayei, A. (2009). TQM consultant selection in SMEs with TOPSIS under fuzzy environment. Expert Systems with Applications, 36(2), 2742-2749.

Triantaphyllou, E. (2000). Multi-criteria Decision Making Methods: A Comparative Study. Kluwer Academic, Dordrecht.

Van Leekwijck, W., Kerre, E.E. (1999). Defuzzification: criteria and classification. Fuzzy Sets and Systems, 108, $159-178$.

Ye, F. (2010). An extended TOPSIS method with interval-valued intuitionistic fuzzy numbers for virtual enterprise partner selection. Expert Systems with Applications, 37(10), 7050-7055.

Yeh, C.H., Chang, Y.H. (2009). Modeling subjective evaluation for fuzzy group multicriteria decision making. European Journal of Operation Research, 194(2), 464-473.

Yurdakul, M., Ic, Y.T. (2009). Analysis of the benefit generated by using fuzzy numbers in a TOPSIS model developed for machine tool selection problems. Journal of Materials Processing Technology, 209(1), 310-317.

Zavadskas, E.K., Antucheviciene, J. (2006). Development of an indicator model and ranking of sustainable revitalization alternatives of derelict property: a Lithuanian case study. Sustainable Development, 14(5), 287-299. 
Zavadskas, E.K., Antucheviciene, J. (2007). Multiple criteria evaluation of rural building's regeneration alternatives. Building and Environment, 42(1), 436-451.

Zavadskas, E.K, Kaklauskas, A. (1996). Multiple Criteria Evaluation of Buildings. Technika, Vilnius.

Zavadskas, E.K., Zakarevicius, A., Antucheviciene, J. (2006). Evaluation of ranking accuracy in multi-criteria decisions. Informatica, 17(4), 601-618.

Zavadskas, E.K, Kaklauskas, A., Turskis, Z., Tamošaitienė, J. (2009b). Multi-attribute decision-making model by applying grey numbers. Informatica, 20(2), 305-320.

Zavadskas, E.K., Kaklauskas, A., Vilutiene, T. (2009a). Multicriteria evaluation of apartments blocks maintenance contractors: Lithuanian case study. International Journal of Strategic Property Management, 13(4), 319-338.

J. Antucheviciene $\mathrm{PhD}$, associate professor at the Department of Construction Technology and Management at Vilnius Gediminas Technical University, Vilnius, Lithuania. Research interests: sustainable development, construction management, multiple criteria analysis and decision-making theories.

A. Zakarevicius DrSc, professor at the Department of Geodesy and Cadastre at Vilnius Gediminas Technical University, Vilnius, Lithuania. Research interests: investigation of the recent geodynamic processes, multiple statistical modeling and processing of measurement results.

E.K. Zavadskas is principal vice-rector of Vilnius Gediminas Technical University, and head of the Department of Construction Technology and Management at Vilnius Gediminas Technical University, Vilnius, Lithuania. He has a PhD in building structures (1973) and DrSc (1987) in building technology and management. He is a member of the Lithuanian and several foreign Academies of Sciences. He is Doctore Honoris Causa at Poznan, Saint-Petersburg, and Kiev universities. He is a member of international organizations and has been a member of steering and programme committees at many international conferences. E.K. Zavadskas is a member of editorial boards of several research journals. He is author and co-author of more than 400 papers and a number of monographs. Research interests are: building technology and management, decision-making theory, automation in design and decision support systems. 


\section{Rangavimo rezultatu, taikant skirtingus daugiatiksliu sprendimu prièmimo metodus, sutapimo vertinimas}

Jurgita ANTUCHEVIČIENĖ, Algimantas ZAKAREVIČIUS, Edmundas Kazimieras ZAVADSKAS

Šio tyrimo metu norima nustatyti objektyvius alternatyvų prioritetu eilès sutapimus (nesutapimus), kuomet racionaliu sprendimu paieška atliekama taikant kelis skirtingus daugiatiksliu sprendimų prièmimo metodus. Metodika rangavimo rezultatams vertinti parengta sprendžiant realu apleistų pastatų sutvarkymo atvejį bei modeliuojant eksperimentinius uždavinius. Alternatyvu prioritetams nustatyti naudoti COPRAS, TOPSIS ir VIKOR metodai, papildyti neraiškiuju aibiu elementais. Skaičiavimo rezultatu neapibrèžtims ịvertinti taikyti matematiniai statistiniai metodai. Pasiūlyta metodika alternatyvų rangụ sutapimams (nesutapimams) nustatyti. 